Brit. F. vener. Dis. (1971) 47, 216

\title{
Witkop disease
}

\section{Two 'favoid' cases due to syphilis}

\author{
P. S. JAIN *
}

General Hospital, Abuja, North Western State, Nigeria

\begin{abstract}
'Witkop', a persistent, crusting affection of the scalp causing alopecia and scarring (Kaalkop), occurs most commonly among the Bantu of Bechuanaland and Rhodesia. The onset is usually in childhood, in the age group 2 to 12 years, and the disorder may persist well into adult life. Until comparatively recent times it was accepted as an uncommon manifestation of syphilis, in most cases congenital, though an acquired case was described by Fraser (1922), and both congenital and acquired cases were described by Marshall and Wilson (1949). Fraser recognized a triad in congenital syphilitics in Bechuanaland comprising scalp lesions, mulberry molars, and chronic rhinitis. Those describing the condition as associated with syphilis often refer to the scalp as having a 'favoid' appearance-thus Sutton (1956) defines witkop as 'a favoid condition of the scalp ... seen only among syphilitic natives of South Africa'. Indeed, as early as 1915, Mitchell and Robertson considered that a fungus was associated, having isolated an organism resembling $T r$. schoenleinii in four cases, but Fraser (1922) denied the existence of fungus infection. However, nowadays it is stated authoritatively (Rook, Wilkinson, and Ebling, 1968) that witkop 'at one time thought to be due to syphilis is now known to be favus', an opinion based on the work of Murray, Freedman, Lurie, and Merriweather (1957). Willcox (1964) also defined witkop as 'considered by some as being due to syphilis but now regarded as due to favus', and suggested that those cases in which there was evidence of syphilis arose by the coincidence of endemic syphilis and favus, both infections being prevalent in the particular community.

The author presents two cases of witkop in boys, in both of which there was no evidence of fungus infection, and in which serological tests for syphilis proved positive, and the condition healed with antisyphilitic therapy. The cases were additionally unusual in that they occurred in Northern Nigeria.
\end{abstract}

Received for publication September 25, 1969

^Present address: Department of Surgery, A. B. U. Hospital, Zaria, Nigeria

\section{Case reports}

Case 1, a boy aged 10 years, a native of Katagum Division in the Northern States of Nigeria, attended the outpatients department on August 10, 1967. He belonged to a nomadic Fulani tribe engaged in rearing cattle. He had suffered from septic rashes all over his scalp for the last 3 years and had received various treatments at different places but with no lasting benefit. There was no history of any other serious skin disease or of genital sores. He had never been exposed to any venereal infection.

\section{EXAMINATION}

The physical development was normal. The whole scalp was covered over by thick yellowish white crusts, which were matted and dry (Figure). The regional lymph nodes were enlarged but painless. There were no other abnormal findings. Removal of the scabs showed a dull red eroded surface with serous exudate. Microscopical

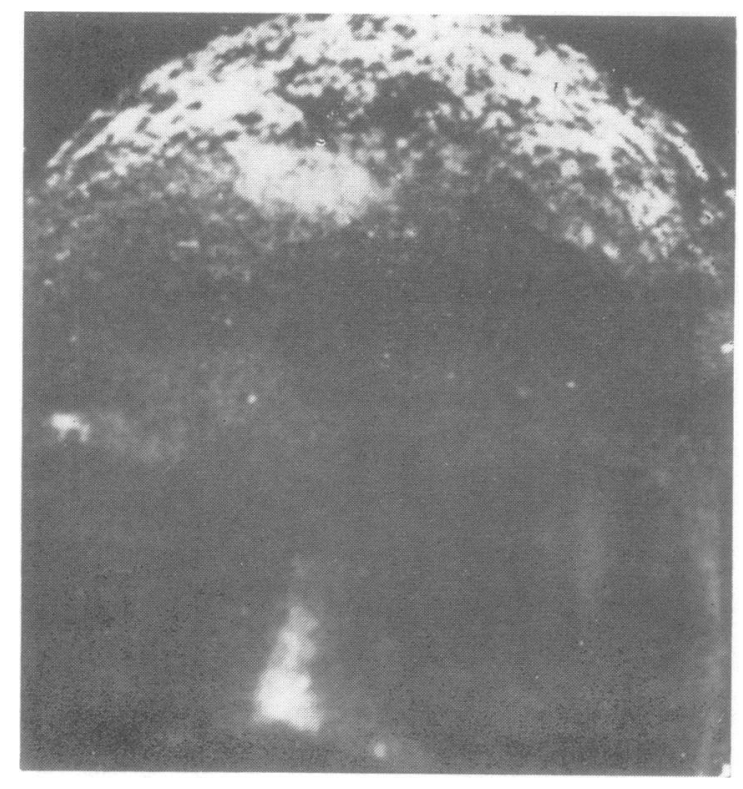

F I G URE Appearance of scalp from the front 
examination and culture of the crusts failed to reveal evidence of fungus infection. Dark-ground examination of serum from the exuding lesions did not show Treponema pallidum. Serological tests for syphilis were positive (VDRL $1: 16$; Kahn +++ ).

$\mathrm{X}$-ray examination of the skull showed no bony changes.

\section{TREATMENT}

$\mathrm{He}$ was given daily intramuscular injections each of 600,000 units of procaine benzyl penicillin in oil containing 2 per cent. aluminium monostearate (PAM) for 10 days and antiseptic dressings were applied.

\section{RESULT}

The lesions healed rapidly, and when he was seen again after 10 weeks, the scalp had completely healed with atrophic scarring. The alopecia was not affected. He was examined just over a year later and there was no sign of recurrence.

Case 2, a Gwari boy aged about 8 years, came to the General Hospital, Abuja, Northern States of Nigeria, on February 10,1969. There was a history that his scalp hair had started falling out in patches about 4 years previously, and that this had been followed by scabbing of the scalp. So far as he knew, none of his family had ever suffered from this disease.

\section{EXAMINATION}

His scalp was covered over by greyish-white crusts with alternating areas of dry white scabbing and atrophic patches. The posterior auricular and cervical lymph glands were enlarged and painless. There were no clinical signs of congenital or acquired syphilis.

Microscopical examination and culture of the scalp material revealed no fungus. Serological tests for syphilis were positive (VDRL $1: 32$; Kahn +++ ).

\section{TREATMENT}

He was given intramuscular injections of 600,000 units of PAM daily for 10 days, and antiseptic dressings were applied.

RESULT

The scalp healed completely. The boy did not return for long-term follow-up.

\section{Discussion}

These two cases of witkop had a close resemblance to favus, but no evidence of fungus infection was found. Serum tests for syphilis were positive, and there was prompt healing after antisyphilitic therapy. It is the author's final opinion that they were mani- festations of congenital syphilis, though confirmation by examination of the parents was not possible. It seems prudent to question the modern assumption that all cases of witkop are due to favus. So far as the author can discover, no cases of witkop have previously been described from this area of Africa.

\section{Summary}

In recent years witkop (white head) has been authoritatively described as being due to favus and not, as formerly believed, to syphilitic infection. Two cases in boys are described, in which there was no evidence of a fungal cause. In both there was serological evidence of syphilis and there was prompt healing after antisyphilitic therapy.

So far as the author can discover, witkop has not previously been described as occurring in Northern Nigeria.

\section{References}

FrASER, A. R. (1922) Brit. F. Derm. Syph., 34, 267

MARShall, J., and Wilson, G. A. (1949) $S$. Afr. med. F., 23, 783

Mitchell, J. A., and Robertson, G. W. (1915) S. Afro med. Rec., 13, 28

MurRay, J. F., Freedman, M. L., LURIE, H. I., an MERRIWEATHER, A. M. (1957) S. Afr. med. F., 31, 65\%

Rook, A., Wilkinson, D. S., and Ebling, F. J. G. (1968) 'Textbook of Dermatology', vol. 1, p. 853. Blackwell Scientific Publications, Oxford

Sutron, R. L., Jr. (1956) 'Diseases of the Skin', 11th ed., p. 406. Mosby, St. Louis

WILLCox, R. R. (1964) 'Textbook of Venereal Diseases and Treponematoses', 2nd ed., p. 273. Heinemann Medical Books, London

\section{Maladie de witkop*; deux cas à allure de favus dûs à la syphilis}

SOMMAIRE

$\mathrm{Au}$ cours des récentes années, la maladie de witkop a été nettement attribuée au favus et non, comme on le croyait auparavant, à l'infection syphilitique. On décrit deux cas chez des garçons dans lesquels on ne trouva aucune preuve d'une origine fongique. Dans les deux cas, la sérologie fut positive et la guérison s'obtint rapidement après un traitement antisyphilitique.

$D$ 'après les informations de l'auteur, la maladie de witkop n' avait pas été décrite jusqu'ici dans la Nigéria du Nord.

^Alopécie avec croûtes blanchâtres du cuir chevelu, suivie de cicatrices atrophiçues (NDT). 